\title{
Performing Communism in the American Dance: Culture, Politics and the New Dance Group
}

\section{VICTORIA PHILLIPS GEDULD*}

The artist is simply reflecting his time. (Martha Graham)

On the stage set of Sing for Your Supper, a limousine transforms into a Madison Avenue bus and a fence holding back a crowd in tuxedos and top hats breaks down. The men don blackened glasses and insert "I Am Blind" signs into their hats. From stage left, four United States Senators enter and perform "an eccentric dance. ... They go through an investigation with futile results." As the Senators prance off, the company sings: "Sell your stocks to your mother, buy them back from your brother." As another scene opens, they continue, "It tickles all of Karl Marx' men/to wreck Tuxedo Park's men."1

Sing for Your Supper opened in 1939 as one of the final productions of the Works Project Administration (WPA), a US government relief agency. As a WPA musical revue, it satirized Uncle Sam as a character who could not keep tune. The production had been in rehearsals for over a year, and government officials had reviewed and sanctioned content that highlighted the weaknesses of capitalism and demanded governmental support for the nation's people. ${ }^{2}$ Its dance scenes were choreographed by Anna Sokolow, who employed dancers from the New Dance Group (NDG) and was also a member of the nongovernmental Workers Dance League (WDL), an offshoot of the Sovietinspired Workers Cultural Federation (WCF).

\footnotetext{
*Victoria Phillips Geduld is $\mathrm{PhD}$ candidate in History at Columbia University. She has an MA in History from Columbia, an MA in English from NYU, and an MBA from Columbia's Business School. She has worked with various dance companies, has extensive management experience, and has written about dance history both in professional and academic journals. She presented the keynote address at the 2008 "Dance is a Weapon" conference held by the Centre National de la Danse Pantin, France, and is the founder and head of the Historic Dance Theatre. Email: LVB3@columbia.edu

${ }^{1}$ Sing for Your Supper, Federal Theatre Project of the WPA, music Lee Wainer and Ned Lehac, book Harold Hecht and Dorothy Hailparn, lyrics Robert Sour, choreography Anna Sokolow, 24 April 1939June 1939, Adelphi Theatre, New York City. Play script available: "Sing for Your Supper," record group 69, stack area 530, compartment 5, shelf 7 (National Archives, College Park, MD, hereafter NACP).

2 “The Federal Theatre Play, Sing for Your Supper," The New York Times, 25 April 1939, 18; John O'Connor and Lorraine Brown, eds., Free, Adult, Uncensored: The Living History of the Federal Theatre Project (Washington, DC: New Republic, 1978), 22.
} 
In 1931 the WCF declared: "Art is a weapon."3 Within six months the NDG premiered in New York City. The following year it appeared as a member of the WDL and deployed the slogan "The dance is a weapon." notes explained: "The working class is growing in number, growing in strength, and growing in knowledge. It is simultaneously developing itself and its weapons. One of its most important weapons is our modern revolutionary dance."5 The NDG and WDL dancers brought Communist propaganda tools to US government culture projects. The US government administrators welcomed, learned from, and imitated the politically expedient Soviet-inspired lessons.

Sing for Your Supper marks a moment of transnational imitation that engaged both Soviet Communism and the USA and locked these opposing governments in a cycle of borrowings, reaction, and mimicry. While Sokolow choreographed for the government's WPA, the Communist New Masses sponsored her WDL Theatre Unit dance company on Broadway. ${ }^{6}$ In 1938, a Special House Committee on Un-American Activities, headed by Martin Dies (Democrat, Texas), labeled the WPA's Theatre Project, "a hotbed of communist infiltration;" these dancers had indeed mastered their performance techniques under Soviet direction and learned its tenets of agitational propaganda. Yet NDG founder Edna Ocko wrote that they were "gentilly pink," not revolutionary Red. ${ }^{7}$ Nonetheless, in August 1939 Congress closed Sing for Your Supper along with the entire WPA Theatre Project, foreshadowing the governmental approach to leftist protest-driven theatrical output during the Cold War.

From World War I, the USA and the USSR had defined themselves ideologically in opposition to one another. American capitalism promised an economic frontier; under Marxist-Leninist socialism, equality would emancipate the worker. Since ideology shaped political solutions in both countries, the Soviet and US governments searched for methods of influence to promote national tenets. The governments became joined in opposition as they borrowed cultural forms in a cycle of escalating imitation. In the 1920s, the Soviet state imported the American modern dance form, and in 1932 sought to export Communist ideology through American dancers. Subsequently, the US government deployed Communist-trained dancers to set the stage for American propaganda during the New Deal. In the Cold War, the USA used indigenous culture and its

\footnotetext{
${ }^{3}$ Communist Party of the U.S. of America (CPUSA) archives, Tamiment Library and Robert F. Wagner Archives, Bobst Library, New York University (hereafter CPUSA archives), "Report of the conference that Organized the Workers Cultural Federation of the New York District," reel 194, delo 2579; "Art is a Weapon: Program of the Workers Cultural Federation," New Masses, August 1931, $11-13$.

4 "New dance group: first annual recital," New Dance Group Archives, New York, courtesy of Rick Schlussel, Artistic Director (hereafter NDG archives).

5 "New dance group: first annual recital," NDG archives.

${ }^{6}$ John Martin, "Anna Sokolow in dance recital," The New York Times, 27 February 1939, 17.

${ }^{7}$ Edna Ocko, Workers Theatre, cited in Stacey Prickett, "Reviewing the left: the dance criticism of Edna Ocko," in Lynn Garafola, ed., Of, By, and For the People: Dancing on the Left in the 1930s [Studies in Dance History, 5 (no. 1, 1994), 72].
} 
modern dance as a weapon. The transnational history of 20th-century modern dance epitomizes this story of rivalry and imitation. This transnational choreography spanned decades and led to parallel thinking: in 1933 a Communist dancer wrote: "Bad art is bad propaganda, and good art is good propaganda." "8 Central Intelligence Agency (CIA) memo in 1952 put the point in this way: "If a work is to be good propaganda it should also be good art."

The deployment of dance as propaganda in both nations became eerily similar. Seeded by the Communist Party, the NDG produced choreographers and trained dancers who shaped the course of American dance. ${ }^{10}$ At the inception of the NDG, as the Communist Party of the United States of America (CPUSA) co-opted modern dancers, these artists echoed the changing Party ideals and use of propaganda tools. The NDG broke with the CPUSA, survived competition from the WPA, adopted nationalistic tenets during World War II, and has continued into the 21 st century.

During the 20th century, the NDG produced enduring works in the modern field. Choreographers who studied, performed, or taught with the NDG included those who worked on the concert stage, in ballet, and on Broadway such as Jerome Robbins, Alvin Ailey, Donald McKayle, and José Limón. In addition, the NDG's approach to the dance had an impact on iconic artists such as Martha Graham, who remolded their works during the 1930s and 1940s, deploying the tactics of political dance to moderate modernism for popular consumption. The NDG reshaped the American dance terrain. Yet weighted by Cold War baggage, historians have obscured the political ties of the NDG, which could be accused of implanting Communist ideas into the national culture. In 1948, dance critic Margaret Lloyd opened her history of the NDG: "There are no Reds in modern dance today." 11 Seventy-five years after their

\footnotetext{
8 "The groups participating in the Workers Dance League festival: red dancers," Workers Dance League Bulletin: Festival Issue Souvenir Program (June 1934), New York Public Library for the Performing Arts-Dance Division, New York (hereafter NYPL-DD).

${ }^{9}$ Quoted in Daniel Leab, Orwell Subverted: The CIA and the Filming of Animal Farm (University Park, PA: Pennsylvania State University Press, 2007), 25.

${ }^{10}$ Stacey Prickett, "From workers dance to new dance," Dance Research, 7 (Spring 1989), 47 \& 63.

${ }^{11}$ Margaret Lloyd, The Borzoi Book of Modern Dance (New York: Alfred A. Knopf, 1949), 173-4. The books on modern dance published before Lloyd's survey ignored the NDG. John Martin, the New York Times dance critic from 1927, did not include the NDG in any of his books: The Modern Dance (New York: Dodge Publishing, 1933, reprint Dance Horizons, 1976); America Dancing: The Background and Personalities of the Modern Dance (New York, Dodge Publishing, 1936, reprint Dance Horizons, 1968). Martin wrote that the New Dance League, which had been the WDL, "develops recreational groups for laymen who wish to learn to dance for their own pleasure" (Martin, America Dancing, 12). Although he ignored the highly trained dancers of the NDG in his books, he included them in his New York Times reviews. In 1934 he acknowledged that the NDG was shedding some of its "revolutionary forms" and embracing "art." Later in the year he celebrated the NDG as presenting "first rate material, imaginative, stirring, and in every way choreographic" (Martin "Workers League in group dances," The New York Times, 24 December 1934, 16). He conceded of the NDL in 1935, "The dancers who compose the league's performing group are strictly professional" (Martin, "New Dance League in first recital," The New York Times, 23 December 1935, 15). Don McDonagh, a later influential historian and biographer of Martha Graham, followed Martin and removed the NDG from his genealogy of modern dance. Ellen Graff in her Stepping Left: Dance and Politics in NYC, 1928-1942 (Durham, NC: Duke University Press, 1997, 161), noted that "The New Dance Group has no place in
} 
first performance in 2007, a founding member of the NDG commented on Lloyd's history: "She was trying to protect us."12

Trends in historiography allow analysis to reframe Communist influence on American dance. First, McCarthy-era protectionism once encouraged historians to suppress Communist contact. On the other hand, the fall of Soviet Communism and the 1993 opening of the Soviet archives relating to the CPUSA has allowed historians to unearth connections in less politically charged times. Finally, innovations in transnational history have encouraged historians to search for connections among nations. Unconstrained by a myopic national lens as in the Cold War era, transnational modern dance history demonstrates American culture in play, and influenced by the Soviet nation state posited as the enemy. The NDG challenges historians of the CPUSA who claim Soviet hegemony, as well as those who privilege the "grass roots" expression of Communist ideals. The Soviet Union and the USA entered a cultural dialogue that altered American dance form and resonated in national politics.

Historians of the CPUSA have been locked in a "top-down," "bottom-up" debate. ${ }^{13}$ Led by Theodore Draper in the 1950s, the founders of CPUSA history proposed a strict relationship between Soviet orders and CPUSA action via the Comintern. ${ }^{14}$ Draper was followed by Harvey Klehr, who examined the impact of Soviet hegemony. Klehr and his colleague John Haynes pioneered work in the Russian archives opened in 1993, only to reassert the potency of Moscow's commands in the USA. ${ }^{15}$ Although Coser and Howe's 1950s cultural history depicted Soviet dominance over the CP's organized activities in the USA, they set the stage for the New Left revisionists. Led by Maurice Isserman in the 1970s, these historians emphasized the importance of individual expression. ${ }^{16}$

(footnote 11 continued)

the neat genealogical pattern of extended choreographic families in Don McDonagh's The Complete Guide to Modern Dance.' Most recently, in Nancy Reynolds's history of 20th century dance that spans over 900 pages she wrote only a few paragraphs about the NDG even though she concluded that "most of the important dancers of the 1930s were at one time or another associated with [the NDG]." Yet they are framed as "protest" dancers who "gradually became less political". Nancy Reynolds and Malcolm McCormick, No Fixed Points: Dance in the 20th Century (New Haven: Yale University Press, 2003, 171-172). Reynolds recognized their choreography only outside the political sphere. Ibid., 234.

${ }^{12}$ Rebecca Rosenberg, "Oral history with Rebecca Rosenberg," interview by Victoria Phillips Geduld, 15 March 2007, New York City, [Columbia University Oral History Research Office (hereafter CUOHRO), transcript available upon request].

${ }^{13}$ The use of the term "American" is borrowed from Helen Delpar, The Enormous Vogue of Things Mexican: Cultural Relations Between the U.S. and Mexico, 1920-1935 (Tuscaloosa, AL: University of Alabama Press, 1992), ix. "American" is used to describe events and thoughts occurring in the United States, although she shows the term should rightly be applied to "the Americas."

${ }^{14}$ Theodore Draper, The Roots of American Communism (New York: Viking Press, 1957).

${ }^{15}$ Harvey Klehr, The Heyday of American Communism (New York: Basic Books, 1984); Harvey Klehr, John Earl Haynes, and Fridrikh Igorevich Firsov, Russian documents transl. Timothy D. Sergay, The Secret World of American Communism (New Haven: Yale University Press, 1995).

${ }^{16}$ Irving Howe and Lewis Coser, The American Communist Party: A Critical History, 1919-1957 (Boston: Beacon Press, 1957); Maurice Isserman, Which Side Were You On?: The American Communist Party During the Second World War (Urbana: University of Illinois Press, 1993). 
Isserman's followers stressed a "grass roots" understanding of American "Communisms.",17

Historians of the CPUSA on both sides recognized the importance of dance to the Party. Klehr claimed cultural groups in the USA "excited Communist intellectuals." In keeping with Klehr's thesis of Soviet ideological domination, he stated that the Workers Dance Group's "sole purpose" was to serve the Party by using dance as a medium to inspire the American worker to greater militancy in the class struggle. ${ }^{18}$ In Klehr's model, the Agitprop Department of the CPUSA mandated subjects and the dancers danced. Because he did not explore how they "served the revolution," his neat model excluded the complexities of expression within the cultural movement. Conversely, Howe and Coser proposed Martha Graham's American Document (1938) as an expression of Communist values during the Popular Front. ${ }^{19}$ An interesting argument, but Graham was neither a card carrier nor a self-professed "fellow traveler." ${ }^{20}$ Graham had ties to the Left, yet she claimed herself as fiercely apolitical, a non-joiner. ${ }^{21}$ Howe and Coser's broad-brush historical approach to Communism in the USA that includes any facsimile of a "fellow traveler" in an idealized Popular Front explains little.

In order to claim material agency for participants, historians have whitewashed concrete CPUSA political roots in the dance art. This dislocation undermines the potency of the Communist Party and does not address the nuances of a complex Soviet-US dialogue that had an impact on American cultural history.

The cyclical story of cultural dialogue that engaged the Soviet and US governments opened with the beginnings of modern dance itself. American dancer Isadora Duncan, considered by some to be "The Mother of Modern Dance," unleashed the unexpected cycle of transnational dance borrowings for state purposes. ${ }^{22}$ In America at the turn of the 20th century, private avant-garde culture boomed. Duncan scorned the European conventions of ballet, from the

\footnotetext{
${ }^{17}$ Michael Denning, Cultural Front: The Laboring of the American Culture in the Twentieth Century (London: Verso, 1998). Note the importance of Denning's work to understand the dance as part of his "cultural front" argument.

${ }^{18} \mathrm{Klehr}$, The Heyday of American Communism, 72. Note that the WDG was one of the twelve WDL units. Confusion about the WDG and WDL is understandable. Indeed, many dance historians confuse the NDG with the WDL after it was renamed the NDL.

${ }^{19}$ Howe and Coser, The American Communist Party, 234.

${ }^{20}$ See Agnes de Mille, Martha: The Life and Work of Martha Graham (New York: Random House, 1991); Don McDonagh, Martha Graham: A Biography (New York: Praeger, 1973); Ernestine Stodelle, Deep Song: The Dance Story of Martha Graham (New York: Schirmer Books, 1984).

${ }^{21}$ See Martha Graham, Blood Memory: An Autobiography (New York: Doubleday, 1991). Although she proclaimed herself as apolitical, she wrote "Seeking the Art of an American Dance" in Oliver M. Sayler, ed., Revolt in the Arts: A Survey of the Creation, Distribution and Appreciation of Art in America (New York: Brentano, 1930). Revolt was heavily influenced by thinkers on the far left. In addition, she wrote an anti-Fascist article, "A dancer speaks," TAC, January 1939, 23. TAC was edited by Edna Ocko and was also considered a leftist magazine with strong ties to the Communist Party's Popular Front.

${ }^{22}$ Nora Ambrosio, Learning About Dance: An Introduction to Dance as an Art Form of Entertainment (New York: Kendell/Hunt Publishing, 1994; reprint 2003), 86; Harry Justin Elam and David Krasner, African American Performance and Theatre History: A Critical Reader (New York: Oxford University Press, 2005), 192.
} 
corseted body to the feet bound in pointe shoes. Her body moved unencumbered in a Greek tunic as she danced barefoot. This expressive dance braved physical, cultural, and spiritual frontiers for a new order defined by freedom. She titled her manifesto, "I See America Dancing.",23 As Duncan performed in Bohemian salons, on the streets of Greenwich Village, and toured Europe, the American government took no notice of her work.

The post-revolutionary Russian state, however, saw Duncan as a cultural messenger whose form could be adopted for political purposes. The tenets of her expressive, free style that condemned old European ballet fitted the canon of the new Soviet state. Lenin himself applauded Duncan when she performed in Moscow's Bolshoi Theatre to celebrate the fourth anniversary of the October Revolution. ${ }^{24}$ After she returned to the USA, the Soviets sent her a telegram: "The Russian government can alone understand you. Come to us; we will make you a school." 25 When Duncan arrived in Russia, the Moscow and Petrograd newspapers were not permitted to publish anything but enthusiastic notices of her performances. ${ }^{26}$

In Russia, Duncan's dance became a symbol of emancipation from the monarchy, which was associated with ballet. ${ }^{27}$ In post-revolution Russia ballet connotated the Tsar, and national dance forms had to be disassociated from royalty. In 1925 the Soviet government closed down all dance schools except Duncan's and the Bolshoi and opened the State Academy of Art Science (Gosudarstvennaya Academiya Khudozhestvennykh Nauk [GAKhN]), which focused on techniques to perform "propaganda through dance," demanding the use of "artistic movement to campaign for revolutionary ideas." 28 The state sanctioned the use of modern forms for propaganda purposes. Duncan, her school, and her company were considered a corrective political phenomenon. ${ }^{29}$

In the USA, indigenous modern dance continued to develop outside the state in the late 1920s. While the Soviets promoted Duncan, artists in the USA regarded her as entirely passé. The new modern generation of dancers replaced Duncan's expressive dance with a canon borrowed from the abstract modernist painters and sculptors. They emphasized human emotions while pulling apart visual form. ${ }^{30}$ Although they presented subjects as universal, the language of expression was borne of the individual. In applying this to modern dance, its artists removed the who, why, where, and when. The what remained paramount.

\footnotetext{
${ }^{23}$ Isadora Duncan, "I see America dancing," in Sheldon Cheney, ed., The Art of the Dance (New York: Theatre Arts, 1928).

${ }^{24}$ Elizabeth Souritz, "Isadora Duncan's influence on dance in Russia," Dance Chronicle, 18 (2, “Aspects of dance: Essays in honor of Selma Jeanne Cohen”), 1995, 281-91.

${ }^{25}$ Isadora Duncan, My Life (London: Boni \& Liveright, 1927; reprint New York: W.W. Norton, 1955), 254.

${ }^{26}$ Souritz, "Isadora Duncan's influence on dance in Russia," 288.

${ }^{27}$ Souritz, "Isadora Duncan's influence on dance in Russia," 282.

${ }^{28}$ Souritz, "Isadora Duncan's influence on dance in Russia," 288.

${ }^{29}$ Souritz, "Isadora Duncan's influence on dance in Russia," 288.

${ }^{30}$ Deborah Jowitt, "Dances with sculpture," available online at: www.tate.org.uk/tateetc/issue8/ davidsmith_danceswithsculpture.htm (accessed 23 April 2007). See also Deborah Jowitt, Time and the Dancing Image (New York: W. W. Morrow, 1988).
} 
In 1927 the form arrived as high art when The New York Times and The New York Herald Tribune first hired dedicated dance critics. ${ }^{31}$ The New York Times promoted Martha Graham's Lamentation (1930) as the pinnacle of the modern dance field. ${ }^{32}$

In Lamentation Graham moved on a bench in an empty, darkened stage, stripping the composition of where and when. Indeed, even the who and how of the story were disabled by the costume that hid her body in a cloth tube. Only the core of the dance was relevant: the what, or grief. Her concerts, along with those of Doris Humphrey, became standing room only events for the intelligentsia. ${ }^{33}$ Graham and her cohort of new modern choreographers established their own private schools and performed in high art concert halls. The new abstract modern dance firmly established the American cultural lexicon, and its development took place firmly outside the state. For the abstract modernists content was personal, perhaps cultural, and almost never political. ${ }^{34}$

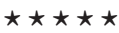

The growing impact of the Depression in the USA inspired some modern dance students into revolt against their apolitical leaders. Many of these students came from working-class immigrant families whose members were losing jobs and homes. With $25 \%$ of the workers unemployed, the dancers and their families were astounded by the lack of governmental response to the Depression. ${ }^{35}$ In addition, they became impatient with the abstract dance that purged subject matter from the dance genre. Along with the workers in their social cohort, the dancers demanded new solutions for the nation. MarxismLeninism promised improved conditions for the population, and the CPUSA was determined to organize cultural forces to support their program and goals.

In November 1930, Waldo Frank led a contingent of Americans to the Soviet Union for the Second World Plenum of the International Bureau of Revolutionary Literature. Edith Segal, the leader of the Red Dancers, unofficially accompanied the group. She was well known to the CPUSA organizers and had staged dance events for them. (At one Madison Square

\footnotetext{
${ }^{31}$ Lynne Connor, Spreading the Gospel of the Modern Dance: Newspaper Dance Criticism in the United States, 1850-1934 (Pittsburgh, PA: University of Pittsburgh Press, 1997).

${ }^{32}$ Lamentation, choreography and costume Martha Graham, music Zoltan Kodaly, 8 January 1930, Maxine Elliot Theatre, New York; John Martin, "Martha Graham acclaimed in dance," The New York Times, 3 February 1931, 29. According to Jowitt, Graham's inspiration for Lamentation was Ernst Barlach's sculpture Beggar Woman (1906) which had been inspired by his trip to Russia.

${ }^{33}$ John Martin, "The dance: artist and audience," The New York Times, 27 December 1931, 94. Note that Martin indicated that Graham's performance was filled to capacity and necessitated calling the fire department.

${ }^{34}$ Note that Graham premiered Revolt at The Little Theatre, New York, 16 October 1927, which was followed by Immigrant: Steerage, Strike, at the same theatre, 22 April 1928. Stodelle noted these dances as Graham's first foray into "straight-lined" and "forceful" works. The critics in 1927 and 1928 did not applaud Graham's political content and sharply criticized these works, which she quickly dropped, while maintaining the new forceful, unromantic style.

${ }^{35}$ Foner, Give Me Liberty!: An American History (New York: W.W. Norton, 2005), Vol. 2, 800-6; David M. Kennedy, Freedom from Fear: The American People in Depression and War (New York: Oxford University Press, 1999) passim.
} 
Garden rally in the 1920s, Segal's dancers leapt barefoot with red flags flying in the air. At the conclusion they were joined by workers on stage to form a human hammer and sickle. ${ }^{36}$ Even the organizers did not understand the modern barefoot form: a Communist leader offered to lay newspaper on the stage floor to protect her dancers' feet. ${ }^{37}$ ) The delegation returned to the USA with a mandate to create the WCF. ${ }^{38}$ In the summer of 1931 New Masses reported on the WCF and declared "Art is a Weapon.",39

CPUSA impotence in the early years of the Depression has been duly noted by historians, although this early failure has been overshadowed by later successes and then the 1950s public hunt for Un-Americans. ${ }^{40}$ Typical of Stalinist propaganda, the Daily Worker and other readily available documents from 1929 through 1932 proclaimed mounting albeit illusory Communist victories. The rhetoric was in keeping with the national mood in the Depression. The nation was economically crippled and people starved in Hoovervilles. According to Communist rhetoric, the Soviet Union represented hope and a new path. Communist newspapers and magazines urged people to travel to Russia to see the Soviet success and to send their children to experience "the socialist miracle." Flyers distributed in New York City in 1932 read, "Capitalist Misery vs. Soviet Prosperity." "41 Yet CPUSA archives show that recruiting efforts to sign up actual members in the USA were abysmal. Masses did attend rallies and protests, but they were not ready to enroll in a revolution. The CPUSA provided the only strong organizational force for protest, but recruitment and retention problems plagued the Communist Party district offices. District bureaus did not return even "brief reports" to the Central Committee Agitprop Department. Calls for local agitprop meetings were not heeded. ${ }^{42}$ The CPUSA was baffled by its own institutional failure to sign up dedicated members during the extraordinary collapse of the US economy. Culture became a tool of recruitment and education.

At the first WCF meeting in 1931, Mike Gold, editor of the New Masses, declared: "You must enter the emotions of the worker, you must bind him to the movement through every part of his fiber." 43 The WCF encouraged worker participation through leisure activities as well as participation in the higher arts. A CPUSA "Report of the Conference that Organized the Workers Cultural Federation of the New York District" proposed the need to get workers to

\footnotetext{
${ }^{36}$ Rosenberg, "Oral history with Rebecca Rosenberg."

${ }^{37}$ Edith Segal, "Interview with Edith Segal," interview by Lesley Farlow, 14 \& 25 January, 1 February 1991, Brooklyn, New York (NYPL-DD).

${ }^{38} \mathrm{Klehr}$, The Heyday of American Communism, 73.

${ }^{39}$ CPUSA archives, reel 194, delo 2579; "Art is a Weapon: Program of the Workers Cultural Federation," New Masses, August 1931, 11-13.

${ }^{40} \mathrm{Klehr}$, The Heyday of American Communism, 85.

${ }^{41}$ See New Masses, 1929-1933; CPUSA archives, reel 234, delo 3036.

42 "From Agitprop Department of the Central Committee To All District Agitprop Directors," 17 February 1932, reel 213, delo 2729, CPUSA archives.

43 "Report of the Conference that Organized the Workers Cultural Federation of the New York District, June 14, 1932," reel 1194, delo 2579, CPUSA archives.
} 
"spend their leisure time with us." The national Communist leaders discussed how to compete with the YMCA that offered workers a swimming pool. Although in 1929 a Party dance had been censured for "commercialization and vulgarization," Communist Party folk dances were now encouraged and heavily advertised in the Worker. ${ }^{44}$ The WCF proposed solutions: from cartoons and lighter feature articles in publications to "more lively and more attractive" revolutionary demonstrations, the Communists would educate the workers in their own American language. The WCF wanted to expand beyond the visual arts and literature, beyond the John Reed Clubs to include workers' theatres, the Workers Film and Photo League, Workers Musicians League, and the dancers. ${ }^{45}$

The education of workers had significant barriers to overcome, and the cultural groups provided new tools. Like their Russian counterpart, the CPUSA battled low literacy. In the USA, English language skills presented a problem for immigrant recruiting. The bulk of the prospective and existing members spoke Finnish, Italian, Yiddish, or Russian. Indeed, the six NDG founders were all first-generation Jewish immigrants, mostly Russian. Calls for May Day celebration rehearsals betrayed the problem of language. The Central Committee Agitprop Department mandated that "it is necessary that all choruses and every one of its members prepare to sing revolutionary songs together in the English language." 46

District leaders asked for simpler classroom outlines that engaged the recruits in foreign languages. The Central Committee Agitprop Department agreed that the idea was good, but offered no resources to help. The branch offices would have to do the translating themselves. ${ }^{47}$ Gold noted at the first WCF meeting that in Russia $90 \%$ of workers were illiterate, a problem "they have solved through cultural methods." 48 He suggested that American cultural projects would solve the language barrier in the USA. Non-verbal cultural disciplines such as art, photography, and dance became central to the Communist efforts to attract and educate workers. ${ }^{49}$

Workers Theatre made its debut just after the WCF call for an increase in cultural output. Leo Hurwitz, the husband of Jane Dudley-the NDG's central organizational lynchpin-edited Workers Theatre. They were part of a

\footnotetext{
${ }^{44}$ Klehr, The Heyday of American Communism, 14. Of the almost 100 cultural organizations included in the Workers Cultural Federation in 1931, there were no membership numbers recorded for a quarter of the groups - a large number for an organization bent on reporting statistics. Although the average membership per group was a healthy 381 participants, the range betrays a less vigorous showing. Indeed, of those reporting numbers the median was a paltry 50 workers.

${ }^{45}$ Reel 194, delo 2579, CPUSA archives.

${ }^{46}$ Reel 194, delo 2578, CPUSA archives.

47 “From District Office \#18, to the Agitprop Department, 27 February 1932," reel 213, delo 2730, CPUSA archives.

48 "Report," reel 2, delo 5, CPUSA archives.

${ }^{49}$ In 1932 the WCF was "reorganized for active work," and Klehr posited that "little more was heard of the WCF" (Klehr, The Heyday of American Communism, 74). Yet the WCF dance units paint an active story if the names are closely followed. The dance unit was one of several artistic outgrowths that thrived during the 1930s in theatre, music, photography, literature, criticism, and art.
} 
New York radicalized intelligentsia including poets, playwrights, musicians, film-makers, and artists involved in the various workers' cultural groups. Edna Ocko, who would found both the WDL and the NDG in 1932, wrote for the magazine and Gold contributed articles. ${ }^{50}$

The magazine's connection to the Party was clear. Workers Theatre reported: "COMRADES: The Agitprop department of the Communist Party called upon the workers theatres in New York for active participation." The editor declared: "This is the moment, when the workers and the working class organizations, recognized the U.S. as an important factor in the revolutionary movement of the working class." 51 It was an artistic call to arms.

Yet by February 1932, the public response to the CPUSA was still lethargic. The Daily Worker printed headlines about membership, solidarity, and the success of protests and rallies, but membership waned. Although the Daily Worker claimed miners' support of a 1932 strike in Kentucky, they were reticent. ${ }^{52}$ However, the strike drew the attention of pre-eminent New York Party members. Led by WCF delegate Waldo Frank, they traveled south to help the workers with speeches and food. On the day of their arrival an off-duty Kentucky law official shot a teenage Communist organizer, Harry Simms. ${ }^{53}$ When Simms died several days later the Worker declared in its usual didactic language, "Because the bosses hate and fear the truth, and for his organizing, because the bosses fear the united efforts of the workers, Harry Simms was murdered by the bosses." 54

According to the Worker, the young revolutionary Simms died a revolutionary death. Yet the only bigger typeface than that proclaiming the tragedy of Harry Simms included a call for money to save the Daily Worker itself. Sales were not covering expenses. ${ }^{55}$ Uniting their lead stories a front page article memorialized Simms because he "worked hard every day to get the Daily Worker into the hands of every worker he could reach." 56 The CPUSA's faltering membership explains the use of Simms as a martyr who sold newspapers.

The sensational reportage of Simms' revolutionary fervor inspired new cultural output. The day Simms was shot, Edna Ocko of Workers Theatre and

\footnotetext{
${ }^{50}$ Although Hurwitz called Workers Theatre a "left wing" magazine that was one step removed from the Communist Party "organs," the tone of the magazine betrays closer ties to the CPUSA. During the McCarthy period Hurwitz was blacklisted and he may have posited the magazine as "left wing" in order to protect those who were able to work, including his former wife and other choreographers. Hurwitz spoke out vehemently about those who named names and his oral history was closed until his death.

${ }^{51}$ Leo Hurwitz, "Dram Buro report," Workers Theatre, May 1932, 5.

${ }^{52}$ John W. Hevener, Which Side Are You On?: The Harlan County Coal Miners, 1931-1939 (Champaign, IL: University of Illinois Press, 2002), 79.

${ }^{53}$ Hevener, Which Side are You On?, 80.

54 “'Carry On Harry Simms’ Fight!—Strengthen the Daily,” The Daily Worker, 17 February 1932, 1.

55 "Recruit 1,000 Members for Communist Party in New York," The Daily Worker, 10 February 1932, 1; "From Agitprop Department of the Central Committee To All District Agitprop Directors," 17 February 1932, CPUSA Archives, reel 213, delo 2729.

56 “Carry on Harry Simms Fight!-Strengthen the Daily," The Daily Worker, 17 February 1932, 1.
} 


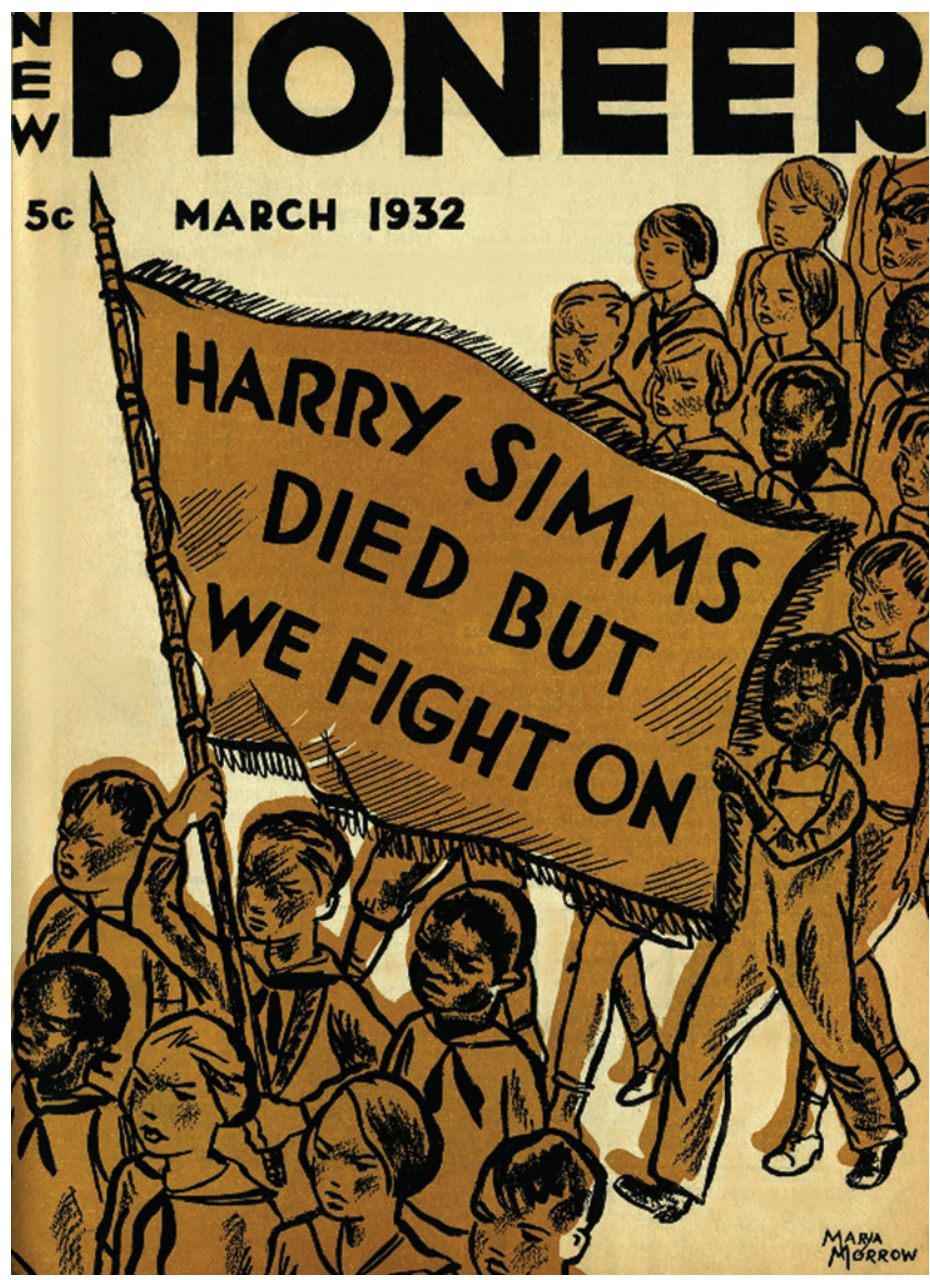

Fig. 1. Cover of the children's magazine, the New Pioneer, celebrating Harry Simms. Courtesy: Tamiment Library and Robert F. Wagner Labor Archives, Bobst Library, NYU.

five other student modern dancers organized the NDG. ${ }^{57}$ The NDG joined workers to "pay tribute to our murdered comrade young Harry Simms" at a rally as the body arrived in New York City by train. ${ }^{58}$ Celebrating its first anniversary in 1933, the NDG leadership remembered: "We felt that our appearance at the mass funeral was a sort of test of our fidelity to our group and

\footnotetext{
${ }^{57}$ Jane Dudley would join the group in late 1932 or 1933. Sophie Maslow began her association in 1933-1934. Anna Sokolow headed the Theatre Unit from 1932.

58 "New dance group: first annual recital," NDG archives; The New York Times, 18 February 1932, 2. "Union organizer dies of wound," The New York Times, 13 February 1932, 15; "Armed forces await Kentucky miners," The New York Times, 15 February 1932, 32; "Miners to protest; troops are called," The Washington Post, 15 February 1932, 2; “Miners' protest session prevented," The Washington Post, 16 February 1932, 2; "Mine strike group parades Wall Street," The New York Times, 17 February 1932, 25; "Slain mine striker lies in state here," The New York Times, 18 February 1932, 2.
} 
manifestation of our willingness to enter the ranks of the working class revolutionary movement." 59 These dancers had come together to create a new language of revolutionary dance. For its first anniversary bulletin in 1933, the NDG echoed the WCF's "Art is a Weapon", and declared, "The dance is a weapon.",60

Under the auspices of the WCF the NDG's Edna Ocko, along with the Red Dancers, Edith Segal and others, started the WDL in Manhattan's Lower East Side, a few doors down from Communist Party headquarters. ${ }^{61}$ The WDL acted as an umbrella organization that included the NDG. By mid 1932 the WDL's 12 units-including the Duncan Dancers (in deference to their Russian comrades), the Red Dancers, the Theatre Dance Unit, and the Harlem Dance Unit, renamed the Harlem Prolets (short for "proletariats")-were as varied as their names, and spanned the spectrum of professionalism. The Nature Friends performers included workers and German immigrant hiking enthusiasts; Sokolow, also a soloist with Martha Graham and at the pinnacle of the modern profession, headed the Theatre Dance Unit. The NDG combined elements of both extremes: it had modern dance professionals who staged productions, performed as soloists in concert halls, and taught in the school; worker-students joined in mass dances at the conclusion of union house performances; one performing unit included only amateur folk dancers. ${ }^{62}$

Through high art cultural disciplines, the CPUSA drew in the intelligentsia of New York, who they hoped would then use art to enlist the masses. The NDG wanted to attack the problems of the day with the new dance language. By 1933 Hurwitz's wife Jane Dudley had joined the NDG alongside Sophie Maslow, who was also active in Party rallies and events. Maslow had trained at Communist camps, and her first cousin was a well-known Party sculptor. Dudley recounted, "So that there was a milieu of people who felt, we all felt, that in some way we could bring changes to society." 63 Hurwitz remembered:

That was a very exciting period, and it reflected all kinds of things. [Workers Theatre] had articles on the revolutionary theatre and the revolutionary film, the revolutionary dance. It then became a kind of a center for a lot of young people in various cultural, theatrical, and film activities. People like Anna Sokolow, Jane Dudley, and Sophie Maslow in the dance. ${ }^{64}$

\footnotetext{
59 "New dance group: first annual recital," NDG archives.

60 "New dance group: first annual recital," NDG archives.

${ }^{61}$ Lynn Garafola, "Writing on the left: the remarkable career of Edna Ocko," Dance Research fournal 34 (no. 1, 2002), 53-61. In April 1932 all units of the WCF reorganized (Klehr, The Heyday of American Communism, 74). Note that Klehr wrote that after the April 1932 reorganization "little more was heard of the WCF." Yet the groups into which the WCF reorganized remained working and potent. The Red Dancers became a part of the Workers Dance League, and the Workers Theatre, Film and Photo League, and Musician's League thrived.

62 "New dance group: first annual recital," NDG archives.

${ }^{63}$ Jane Dudley, Harmonica Breakdown: Speaking about the Dance (Singh Production for the Arts Council of England, dir. Darshan Singh Bhuller and Tom Hurwitz, 15 minutes), available at the NYPL-DD.

${ }^{64}$ Hurwitz, Oral History, transcript 145.
} 


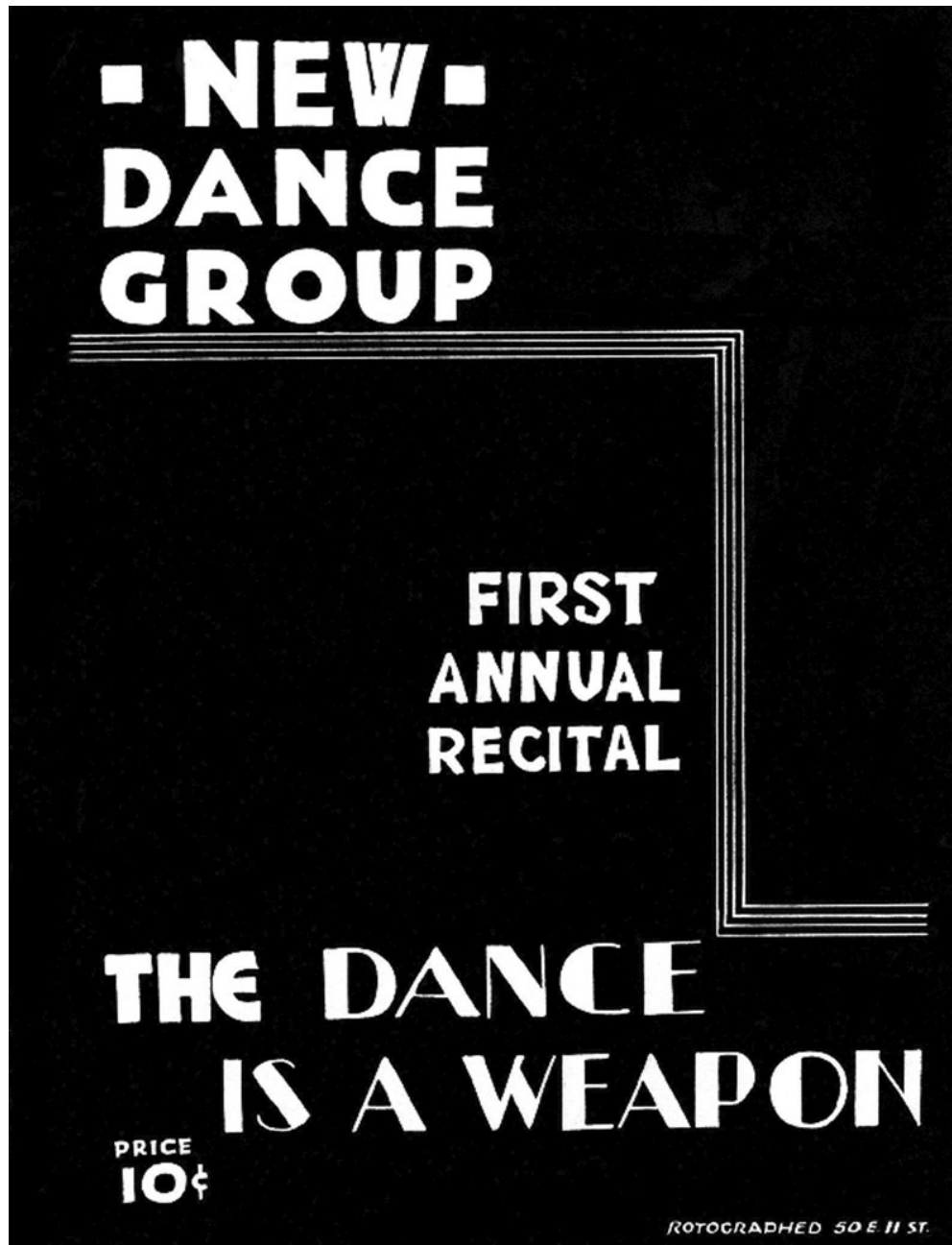

FIG. 2. Courtesy: Rick Schlussel, Artistic Director, New Dance Group Archives, New York City.

Ocko wrote that they performed "bearing the message of the fighting, class conscious proletariat." ${ }^{65}$ A founding member of the NDG remembered: "Revolt was in our bones.",66

Although the NDG's historians have decoupled the early NDG from the Communist Party, even in the early 1930s the NDG was not overt about its link to party activities because anti-Communist activity increased with the start of the Depression. ${ }^{67}$ Hurwitz remembered that, although during the 1930s,

\footnotetext{
${ }^{65}$ Ocko, "The new dance group," cited by Prickett, "Reviewing the left ...," in Garzfolz, Of, By, and For the People, 71-72; Workers/New Theatre, July-August 1934.

${ }^{66}$ Rosenberg, "Oral history with Rebecca Rosenberg."

${ }^{67}$ August R. Ogden, The Dies Committee: A Study of the Special House Committee for the Investigation of Un-American Activities (Washington, DC: The Catholic University of America Press, 1944), 20.
} 
"you didn't have the equivalent of the suppression that happened in the McCarthy period, the systematic harassment," times were not "free from pressure on people with radical ideas." ${ }^{\prime 68}$ In May 1930 Congressman Hamilton Fish (R-NY) had declared, "We propose to deport all alien Communists."69 House Resolution 250 appropriated $\$ 25,000$ for a Special Committee to investigate Communist Activities in the United States to be led by Fish. Hearings covered a wide geographic territory, including major eastern cities, the South, and the West. When the Fish committee issued its conclusions in 1932, the report proposed to outlaw the Communist Party. Although various Congressmen considered the report "stupid and dangerous", Fish disseminated 36,000 copies which found an audience. ${ }^{70}$

However, it was not the McCarthy era. Newspapers poked fun at the Fish report. ${ }^{71}$ The CPUSA Agitprop Department suggested slogans for rally placards denouncing the Congressman. Fish himself debated the issues at a public forum, "Communism versus Capitalism," sponsored by New Masses, which was able to dedicate a February 1931 Valentine's Day issue to Fish, with a picture of a dead fish. Nonetheless, the threat was real and Fish might have been pleased to deport most of the NDG membership.

NDG never used the word "Communist" in their bulletin, although it wove direct ties to the CPUSA into its brochure through language cues obvious to audiences in the 1930s. Dancers were not performers, students, or dancers, they were "revolutionary comrades." Like the CPUSA, the NDG was led by a "Secretariat." The Soviet workers competed in Spartakiades, or non-elitist sports games; these dance units competed in dance Spartakiades. A key to the NDG Party affiliation was embedded under the heading "Our Social Activities." Aside from parties, membership meetings, lectures "of a political nature," and "mass folk dancing," the NDG proclaimed: "Our comrades have on various occasions also shown their solidarity with workers in other revolutionary organizations at such times as August first, March fourth and May first." 72 These particular dates had immense Party significance.

August 1 marked annual Communist anti-war rallies. ${ }^{73}$ The CPUSA published a pamphlet in 1929 stating, "August 1 was set aside by the Communist International as a day of strikes and mighty mass demonstrations in every country in the world." ${ }^{, 74}$ On August 1, 1932, demonstrations took place throughout the nation and internationally. ${ }^{75}$ The Chicago Tribune

\footnotetext{
${ }^{68}$ Hurwitz, "Oral history with Leo Hurwitz," transcript 2-77.

${ }^{69}$ Ogden, The Dies Committee, 22. Also see Congressional Record 71-2, 22 May 1930, 9391-2; Hamilton Fish, Jr., "The Menace of Communism," Annals of the American Academy of Political Science, 156 (July 1931), 54-61.

${ }^{70}$ Ogden, The Dies Committee, 27-31. A plethora of bills were introduced in the 72 nd Congress to combat Communism, including one by Representative Martin Dies (D-TX).

71 "Soviet papers poke fun at Fish report," The Washington Post, 21 January 1932, 7.

72 "New dance group: first annual recital," NDG archives.

${ }^{73}$ Reel 194, delo 2579, CPUSA archives.

${ }^{74}$ Reel 272, delo 3475, CPUSA archives.

75 “'Rally to protest veterans' eviction," The New York Times, 1 August 1932, 3.
} 
described the "ugly mood" of the crowds who "booed capitalists depicted in caricature on posters. The placards reiterated demands with the usual violence for free bread, free rent...," and declared "Down with Capitalism." Hamilton Fish got placard attention alongside denunciations of the bourgeoisie and calls for bread, and posters demanded freedom for the Scottsboro Boys. ${ }^{76}$ The Tribune concluded: "There was one American flag lost in a sea of Red banners." 77 The NDG performed Hunger (c. 1932) and Uprisings (c. 1932). The NDG's Revolt (c. 1932) encapsulated the mood of the Communist Party rallies.

May 1 was immensely significant for the Communist Party internationally. ${ }^{78}$ The NDG consistently attended and performed in May Day parades and events. The May Day event in 1932 claimed particular significance. From all over North America, including Philadelphia, Detroit, and other urban cities, to Madrid, Moscow, London, Santiago, Warsaw, Hamilton (Ontario), Berlin, London, Mexico City, Vienna, and Havana the Communists marched en masse. ${ }^{79}$ The papers in New York, Los Angeles, and Chicago reported that in Moscow "2,000,000 Reds March" as they "led the world in the traditional day of the worker." ${ }^{80}$ Because New York City officials expected trouble, they would not issue a permit to rally on May 1 to the CPUSA. ${ }^{81}$ But on May 1,1932 , the NDG staged a "mass dance" to celebrate May Day at the Bronx Coliseum. ${ }^{82}$ Four years later, Maslow choreographed May Day March for the concert stage.

The NDG intentionally crafted the "proletariat" form to be accessible to workers, thus following the mandates of the WCF and the CPUSA. For Communist inspired dance art, the five "Ws" were paramount. In order for dance to be effective propaganda, the who, what, where, when and why had to be clearly and readily available to the audience. In order to accomplish their goal of creating agitprop in American dance, the modern dance student founders of the NDG modified the indigenous form to comply with Soviet inspired propaganda maxims.

In 1934, NDG leader Jane Dudley published a "how to" dance article in Workers Theatre. ${ }^{83}$ In "Mass Dance," Dudley stated that all dancers had to

\footnotetext{
${ }^{76}$ Reel 194, delo 2579, CPUSA archives.

77 “'Big New York protest at war by Communists," Chicago Daily Tribune, 2 August 1932, 5.

${ }^{78}$ Reel 154, delo 2004, 36, CPUSA archives.

79 "May Day riots dot world, but only 3 are slain," Chicago Daily Tribune, 2 May 1932, 5.

80 “2,000,000 Reds march by Lenin's tomb on May Day,” Chicago Daily Tribune, 2 May 1932, 4. See also "Reds mass for peace," Los Angeles Times, 2 May, 1932, 1; "20 hurt as police end Philadelphia parade," The New York Times, 1 May 1932, 21; "Many nations to ban May Day disorders" and "Troops called in Europe and Latin America to prevent threatened May Day disorders," The New York Times, 1 May 1932, 1; "Riots loom today in many countries," The Washington Post, 1 May 1932, 1.

81 "May Day parades to be held today," The New York Times, 30 April 1932, 18.

${ }^{82}$ The "Central Committee Instructions for May 1st" included a section titled: OBJECTIVES. Its mandate was to use May 1 to "to popularize more widely the socialist achievements of the Soviet Union," reel 154, delo 2004, 41, CPUSA archives; "New dance group: first annual recital," NDG archives.

${ }^{83}$ Jane Dudley, "Mass dance," New Theatre, December 1934, 17-8; Lynn Garafola, "Writing on the left."
} 
receive a lesson to "educate (propagandize)" before the choreography could even begin. Themes for agitational dances included "important days, historical events in the class struggle, anti-war issues, Negro rights, class war prisoners, Fascism." 84

Dudley outlined her recent composition (Strike), which required three groups of bodies: "the pickets, the militia, the workers." Some performers were untrained workers, while some were professionally trained modern dancers. The work opens with the workers performing "rhythmic worker movements" along the back of the stage. Dudley required dancers to create their own individually expressive movements based on their experiences as workers. One dancer could pantomime hammering, as another body might enact a winding gear. The militia marches in from the wings and stands in front of the workers. Enter the pickets. As the pickets picket, the militia "shoulders guns." The next tableau includes a protest march and the death of protesters. Finally, the workers join the demonstration and defeat the militia. At the conclusion the workers and pickets rise up in unity. ${ }^{85}$ Strike presented the "Ws" in no uncertain terms.

The WDL units danced in union halls, at rallies, and at marches, and the NDG school enrolled over 800 workers. ${ }^{86}$ Concurrently in Russia, the statesupported Duncan school produced no new dance and efforts to use it for propaganda failed. ${ }^{87}$ Anna Sokolow's partner, composer Alex North, observed, "the art of the dance in the Soviet Union lags behind." 88 Dance Observer reported disappointment in the Slavic Isadora Duncan dancers who "have not developed anything beyond the original Duncan style." 89 Edith Segal had traveled with the WCF delegation in 1930-1931 and showed officials her revolutionary dance, yet she was largely untrained in the new modern form. Between 1933 and 1934, the Soviet state invited members of the WDL to the Soviet Union to teach their new and improved American modern dance. ${ }^{90}$ Upon arriving in Russia with North, Sokolow reported that she was awed by the steel plant at Magnitogorsk and the theatre. Sokolow and others worked in Moscow, teaching the new form to "Russian dance specialists." ${ }^{91}$ Although she wrote that the Soviets "clung tenaciously to the [ballet] dance form," the state invited her back for a year-long tour of duty in $1934 .^{92}$ While exporting

\footnotetext{
${ }^{84}$ Dudley, "Mass dance," 17.

${ }^{85}$ Dudley, "Mass dance," 18.

${ }^{86}$ Workers Dance League Bulletin: Festival Issue Souvenir Program, available at the NYPL-DD.

${ }^{87}$ Souritz, "Isadora Duncan's influence on dance in Russia," 288.

${ }^{88}$ See Alex North, "Dance in the Soviet Union," Dance Observer, May 1934, 1.

${ }^{89}$ Marjorie Church, "The Dance in the U.S.S.R.," Dance Observer, October 1936, 88.

${ }^{90}$ In addition to Sokolow, other dancers taught in the Soviet Union, including Pauline Koner. See North, "Dance in the Soviet Union"; Church, "The Dance in the U.S.S.R."; Edna Ocko, "Three interviews with Russian dancers," Dance Observer, January 1938, 5.

${ }^{91}$ Anna Sokolow, "Return from Moscow," New Theatre, December 1934, 27-8.

${ }^{92}$ Sokolow, "Return from Moscow," 27.
} 
Communist ideology, Stalin imported high-art American modern dance to create a new and improved revolutionary language.

Yet in 1934, the Soviets began to shut down modernism. With Sokolow they "sniffed" at modernist "dilettantism," and retorted, "Unheard of dancing! No acrobatic pirouettes!"93 The Soviets tried to use modern dance, but the form demanded individual expression as the core of its language, conflicting with the collectivist tenets of the state. The Stalinists installed socialist realism, and in 1936 attacked modernists with a Pravda diatribe against Shostakovich's opera Lady Macbeth of Mtsensk. ${ }^{94}$ Indeed, in dance the reversal was even more significant than the expulsion of modernism. The state promoted a return to the nationalist traditions of 19 th-century ballet. Stalin loved "toe dancing," and the return to classical forms mirrored Stalin's political strategy. He purposely used dance to create the illusion of stability during his mass upheaval. ${ }^{95}$ Indeed, by 1938 non-cooperational Russian artists disappeared during the purges. ${ }^{96}$ The Soviet appropriation of American dance technology ended as the state banished modernism and returned to imperial ballet forms. Clearly disappointed, Sokolow criticized the Soviets. She wrote:

The first thing that I did when I landed back in the States was to dash into a cafeteria and have a piece of apple pie and a cup of coffee, fare that is unobtainable in any recognizable form in the Soviet Union. ${ }^{97}$

In 1935, the US government adopted those who had been trained in Soviet-style agitational dance to formulate American propaganda, encouraging the production of new modern dances and using them for political purposes. Roosevelt created the WPA in May 1935, in August he opened the WPA Theatre Project, and the Dance Unit followed in $1936 .{ }^{98}$ The director of the Theatre Project, Hallie Flanagan, had been firmly entrenched in the WCF. Flanagan had toured Europe investigating new theatrical forms and traveled to the Soviet Union to assess its workers theatre. She contributed to "organ" magazines, including Workers Theatre, and she judged Spartakiades. ${ }^{99}$ During one competition she praised Segal's Red Dancers' work Black and White (1931), the first dance to integrate black and white bodies on stage. The NDG's Van der Lubbe's Head won a 1934 dance Spartakiade, receiving both a bronze sculpture of Lenin and good reviews in the New York Times. Responding to their combined use of poetry and dance (the poem "Van der Lubbe's Head" had been published in New Masses), Martin of

\footnotetext{
${ }^{93}$ Sokolow, "Return from Moscow," 28.

${ }^{94}$ For the most recent definition of social realism versus socialist realism see Alejandro Anreus, Diana L. Linden, and Jonathan Weinberg, "Introduction" in The Social and the Real: Political Art of the 1930s in the Western Hemisphere (University Park, PA: Pennsylvania State University Press, 2006), xiv.

${ }^{95}$ Orlando Figes, Natasha's Dance: A Cultural History of Russia (New York: Henry Holt, 2002), 480.

${ }^{96}$ Figes, Natasha's Dance, 483.

${ }^{97}$ Sokolow, "Return from Moscow," 27.

${ }^{98}$ William F. McDonald, Federal Relief Administration and the Arts (Columbus, OH: Ohio University Press, 1969), 568.

${ }^{99}$ See Workers Theatre, 1931-1934; Segal, “Interview with Edith Segal."
} 
the Times wrote that the dance "marks the first success of such an experiment." 100 Under Flanagan the WPA hired many of the WDL and NDG dancers. ${ }^{101}$

In sharp contrast to Stalin's USSR, modern dance thrived under the WPA. Stalin had repressed modernism, and the WPA project proclaimed its productions were "free" and "uncensored."102 Flanagan asserted, "In all periods when the theatre has been a vital part of life, the dance has existed at the core of it," and declared, "America is on the verge of a great dance movement."103 The National Information Service of the WPA released celebratory press releases entitled, "The Federal Theatre Stimulates the Modern Dance."104 The WPA Radio Project launched several programs to promote an understanding of modern dance, including, "Exploring the Seven Arts: New Trends in the Dance." The Art Project made posters for the dance productions. ${ }^{105}$ The Music Project also absorbed out-of-work dancers. The WDL taught the American state a Soviet lesson: good art was good propaganda.

Conversely, the "bourgeois" moderns such as Doris Humphrey who went to work for the government began to express their art in more "proletariat" terms. Their audience was no longer isolated to the concert-going elite intelligentsia. The government hired them "to raise the cultural level of American citizens through exposure and education." These choreographers articulated their desire to perform readable works in 1937 during a WPA radio spot on the arts. Although the dancers defended abstraction as modern, they also melded theatre and dance, "making great strides in its appeal to the public." The stated goal was to "electrify" and reach the masses. ${ }^{106}$ These dancers now called their craft "dance theatre," mimicking the name of Sokolow's unit.

By 1936, not one of the founding six women was still with the NDG. They had earned $\$ 0.50$ per performance with the WDL, while the WPA paid them over $\$ 20$ a week as they worked on Broadway. ${ }^{107}$ They worked in better conditions for regular pay and did not have to give up their socialist beliefs. One NDG founder worked in the Children's Theatre production, Revolt of the Beavers, which dramatized oppressed beaver workers uniting against their capitalist overlords

\footnotetext{
${ }^{100}$ Martin, "The dance: prize winner," The New York Times, 1 July 1934, X5. For Spartakiade prize listings and judging standards, see Workers Theatre, 1932-1934.

${ }^{101}$ Rosenberg, "Oral history with Rebecca Rosenberg, CUOHO."

${ }^{102}$ O'Connor and Brown, eds., Free, Adult, Uncensored.

${ }^{103}$ Hallie Flanagan, "Federal dance project," 14 May 1938, Correspondence and Speeches, "Dance Theatre," record group 69, stack area 530, compartment 9, shelf 3 (NACP).

104 "Correspondence," National Office, General correspondence, Fed-Flan, record group 69, stack area 839, box 9 (NACP).

${ }^{105}$ Station WQXR, "Exploring the seven arts," Federal Radio Division-New York (1936-1939), "Radio Scripts of the NYC Federal Theatre Project, record group 69, stack area 530, compartment 7, shelf 2 (NACP).

${ }^{106}$ Station WQXR, "Exploring the seven arts."

${ }^{107}$ Rosenberg, "Oral history with Rebecca Rosenberg."
} 
with machine guns concealed in their lunchboxes. ${ }^{108}$ Subsequently she transferred to the WPA's Sing for Your Supper, choreographed by Sokolow.

Other Federal Theatre Project units utilized dancers, including the Living Newspaper. The origins of the Living Newspaper genre derived from the Bolshevik revolutionary government's attempt to establish an apparatus of information, news, education, and propaganda. ${ }^{109}$ Flanagan had traveled to Stalinist Russia and viewed the genre in action and transplanted its tenets to the USA under the WPA; a Soviet agitational propaganda form was transposed into a new theater for American audiences to educate the public and promote New Deal agendas.

Roosevelt's culture troops utilized Soviet theatrical forms and the "leftist" sentiment of the WPA members who had worked in Communist front organizations to get bills passed through Congress. ${ }^{110}$ In January 1937, in his second inaugural address, President Franklin D. Roosevelt stated, "I see onethird of a nation ill-housed, ill-clad and ill-nourished." 111 The WPA Living Theatre production One Third of a Nation took its title from this speech and graphically depicted tenement housing. It utilized modern dance choreography to drive the message home. One Third of a Nation, which also echoed earlier WDL works condemning housing conditions, premiered nationally just a few weeks before Roosevelt's Wagner-Steagall housing bill went to the floor. ${ }^{112}$ The bill passed, helped by publicity surrounding the production. ${ }^{113}$

Concurrently, the Communist Party line shifted to working with the state. In 1935, the Seventh Congress of the Comintern declared the need for a Popular Front of all groups opposed to Fascism. The Comintern made an about-face, including socialists and "fellow travelers" in the new project. "Communism is 20th Century Americanism," declared Earl Browder, the CPUSA general secretary while extolling Abraham Lincoln in speeches. ${ }^{114}$

During the Popular Front only two WDL units survived: Sokolow's Theatre Unit and the NDG. As the Popular Front celebrated the nation, the dancers' organizations followed suit as they became less attached to the Soviet machinery. By 1936, Marxist classes were not part of the curriculum at the NDG. A metamorphosis occurred: Workers Theater had become New Theatre and the WDL became the New Dance League (NDL). Dance Observer noted

\footnotetext{
${ }^{108}$ McDonald, Federal Relief Administration and the Arts, 562.

${ }^{109}$ Lorraine Brown, "Introduction" in Liberty Deferred and Other Living Newspapers of the 1930s: Federal Theatre Project (Fairfax, VA: George Mason University Press, 1989), ix.

${ }^{110}$ Sharon Musher, "A New Deal for art: controversy and relevance in public art of 1930s America," lecture at Columbia University, 27 March 2007.

${ }^{111}$ Franklin D. Roosevelt, “'One third of a nation': second inaugural address”, 20 January 1937, available online at: www.historymatters.gmu.edu/d/5105/(accessed 20 March 2007).

${ }^{112}$ The Wagner-Steagall bill, or the Housing Act of 1937, was created to begin a proposed long-term government role in housing under the US Housing Authority. Robert S. Allen wrote an article in The Nation entitled "Roosevelt fights back" explaining Roosevelt's struggle to get housing legislation passed (The Nation, 21 August 1937, 187).

${ }^{113}$ Musher, "A New Deal for art."

${ }^{114}$ Earl Browder, What is Communism (New York: Workers Library Publishers, 1936); Denning, The Cultural Front, 127.
} 
that NDL had "but twenty avowed Communists." The NDL then incorporated itself into the American Dance League. Modernists like Graham and Humphrey joined the political dancers in the League. The radical politics of the NDG were centering in American life. ${ }^{115}$

Dudley's work Charity is a case study of the evolution of the NDG's Communist Party ties alongside national politics from 1932 through 1935. In 1932, Dudley was exposed to the Party line regarding charitable giving which argued, that "Capitalist charity turns workers into beggars unfit for the classstruggle. Charity is thus clearly a capitalist instrument of deception and oppression."116 Articles in the Daily Worker attacked charity organizations, particularly the Salvation Army, declaring "Charities Deny Aid to Workers Owning a Bathtub." 117 Workers Theatre suggested plays for workers, cultural organizations to mount, including "Charity."118 The NDG performed the dance Charity under Dudley's direction in 1933 as part of a program, just after Parasite and before Fingoisms.

Although the play titles issued by Workers Theatre mirrored CPUSA concerns, none of the American play scripts contained the expected straightfaced Communist doctrinal diatribes. Like the theatrical "Charity," Dudley's Charity utilized comic satire and American form. The worker audiences laughed as the dancers marched on stage, legs turned out as they whisked into the imperialist ballet's passés, hands pressed into an inverted prayer position, dressed in Salvation Army bonnets. The unemployed "proletariat" characters danced in the modern form, with parallel legs and powerful bodies. Charity was American Communist comedy.

In 1935, Dudley revived Charity, echoing the changing political climate. ${ }^{119}$ Charity had an important message in support of New Dealers: privatized social programs had not supported the population. Performances of Charity moved from union houses to legitimate theatres. In March the mainstream Dance Observer reviewed Charity and wrote that it received "a hearty response."120 The audience both understood and welcomed the message that the state bore responsibility for its poor. Martin of the Times conceded, "Its satire is so deadly,

\footnotetext{
${ }^{115}$ In late 1935 Ocko urged NDG students to enroll in the Workers School to learn Marxist ideology. See Prickett, "Reviewing on the left"; "Nadia Chilkovsky of the Workers Dance League" Dance Observer, August/September 1934, 68.

${ }^{116}$ Reel 194, delo 2578, CPUSA archives. In the District document the importance of cultural activities was also reiterated and dance was called to action to "serve as a weapon in the class struggle." Each cultural division was called on to "carry the message" to all workers "through its particular cultural medium." The artists were told to abandon "art for arts sake" and "serve in the class war."

117 "Charities deny aid to workers owning a bathtub," The Daily Worker, 9 February 1932, 2.

${ }^{118}$ Other titles echoed NDG's dances: "Fight against starvation" and "Breadline" (Hunger), "The miners are striking" (Harry Simms), "Art is a weapon" ("Dance is a weapon in the class struggle"), "The fight goes on" (Strike), "Liberty USA" (Parasite), "Hands off" (Anti-war Trilogy), and "We demand" (Uprising).

${ }^{119}$ M.J.S., "Workers Dance League," Dance Observer, 2.11, January 1935, 4-5.

${ }^{120}$ L.H., "Workers Dance League," Dance Observer, 2.3, March 1935, 29-30.
} 
and at the same time so funny, that even one's critical reservations cannot stand up against it."121 The revival of Charity in 1935 coincided with a year of dramatic political and cultural changes, both in the Soviet Union and the USA.

Like the converging lines of politics in the USA, the two dance worlds began to meld in 1935. While maintaining the NDG, its leaders, Dudley and Maslow, studied and performed with Graham. ${ }^{122}$ By 1936, Dudley and Maslow's stature as dancers grew as work for Graham increased and their own political works became more modern. Conversely, Graham's works become more political as the Popular Front embraced loosely allied "fellow travelers" and celebrated the USA. Indeed Graham wrote an anti-Fascist article for the Popular Front arts magazine TAC - founded by Edna Ocko, the WDL and NDG founder. ${ }^{123}$

The NDG and Graham joined with the American Dance League in Dances for Spain to support the Spanish Civil War. ${ }^{124}$ Graham was anti-Fascist, the NDG was pro-Communist, but the dancers gathered with a politically infused choreography that was both refined and accessible. During concerts sponsored to support medical efforts in Spain all the modern dances contained the five "Ws." The works certainly privileged the what, following the modernist dictates of Lamentation. The choreographers built dances of grief and anger. Yet Graham, the icon of abstract modernism, reinserted the other four "Ws:" the who was women; war contained the why of the work; the where was Spain. Most importantly, Graham specified the when: the immediate political moment.

As the WPA Theatre and Dance Projects struggled to maintain government support, the state considered dance for nationalist purposes. ${ }^{125}$ In 1937, President and Mrs. Roosevelt invited Graham to perform at the White House, although the Office of Protocol was concerned about her bare feet. ${ }^{126}$ In 1938 , Graham presented American Document, danced to the words of Abraham Lincoln's Gettysburg Address. ${ }^{127}$ Like the NDG's use of spoken poetry to

\footnotetext{
${ }^{121}$ John Martin, "The Dance," New York Times, 13 March 1935, 21.

${ }^{122}$ Jane Dudley, "Interview with Jane Dudley," Bennington School of the Dance Project at Columbia University, Oral History Research Office, interview by Theresa Bowers, 20 December 1978; Sophie Maslow, "Interview with Sophie Maslow," Bennington School of the Dance Project at Columbia University, Oral History Research Office, interview by Theresa Bowers, 29 November 1978 and 3 February 1979.

${ }^{123}$ Martha Graham, "A dancer speaks," TAC, January, 1939, "WPA Federal Theatre Project," record group 69, stack area 530, box 116, folder 23 (NACP).

${ }^{124}$ Julia Foulkes, Modern Bodies: Dance and American Modernism from Martha Graham to Alvin Ailey (Chapel Hill, NC: University of North Carolina Press, 2002), 122.

${ }^{125}$ Graham had come under increasing scrutiny for her abstract dances, even by critics who presented her work as the standard of modernist excellence. Certainly Graham was not exclusively influenced to embrace accessible theatrical devices only by the New Dance Group and members of the WDL. Indeed, Doris Humphrey, who did not emerge from political dance roots, also began experimenting with the use of texts in modern dance to make works more easily understood. Yet the NDG and WDL groups were the only groups who were performing dances with theatrical content before Graham adopted the style.

${ }^{126}$ McDonagh, Martha Graham, 120. Russell Freedman, Martha Graham: A Dancer's Life (New York: Clarion Books, 1998), 79; Foulkes, Modern Bodies, 126.

${ }^{127}$ American Document, choreography Martha Graham, music Ray Green, set and costumes Arch Lauterer, 6 August 1938, Vermont State Armory, Bennington, VT.
} 
impart a political message with Van der Lubbe's Head, Graham used politicized words as the background to explicate her dance. Graham featured Dudley and Maslow in the work. It was a huge success, and the two dancers toured nationally with Graham and American Document, while also fitting in performances of their own works at the NDG.

In August 1939, the WPA Theatre Unit was shut down, in part because of the Red-baiting pressure exerted by the hearings held by Chairman Martin Dies' Special Committee on Un-American Activities. Publicity linking the Theatre Project to the Communist Party had erupted with the start of the WPA program in 1935. In 1937 Flanagan warned regional directors that they were being watched. After loud accusations of subversive intentions she had to approve all play scripts. ${ }^{128}$

In 1938, the Dies' Committee brought Flanagan herself under attack. Although she had travelled extensively internationally, her trip to Russia was a point of contention. Newspapers and the press largely supported Dies. ${ }^{129}$ Even the absurdity of the attacks did not protect the unit, as when one Committee member demanded information about the suspected Communist playwright Christopher Marlowe (who had died in 1593). Another congressman implicated the popular American child actress Shirley Temple. Although Congress allowed the WPA at large to limp ahead after 1939, and other arts units garnered state support, Congress and the Senate terminated the Theatre unit.

The summer of 1939 brought government betrayal to radical modern dance from both sides. Sing for Your Supper closed on Broadway in June 1939 as government funding for the Federal Theatre Project came to a halt. In addition, modernism was no longer sanctioned by Moscow, and Stalinist ideology also became a problem for many of the American dancers. In August 1939, the Soviet Union signed the Nazi-Soviet Pact, thus reversing its position on Fascism, and destroying support for the Stalin regime among many NDG dancers. In 1939, the NDG professionalized and institutionalized as American as dancers returned from the WPA: the NDG hired its first administrator and applied to the state for not-for-profit status. Sokolow traveled to Mexico for the first time, encouraged by the Mexican muralists, and became known as "the founder of Mexican modern dance." Sokolow's cohort included other disillusioned artists such as NDG dancers who had worked for her in Sing for Your Supper.

At the NDG in the early 1940s, choreographers embraced nationalist sentiment while maintaining some support for the fluctuating Party line. They believed in a leftist social agenda and that protest was American. In 1941, they

\footnotetext{
${ }^{128}$ Hallie Flanagan, "Hallie Flanagan's talk at the meeting of the regional staff, 19 Aug. 1937," National Office, General correspondence, Fed-Flan, "Speeches," record group 839, box 9 (NACP).

${ }^{129}$ Gary Dean Best, The Critical Press and the New Deal: The Press Versus Presidential Power, 1933-1938 (Westport, CT: Praeger,1993); Graham J. White, FDR and the Press (Chicago, IL: University of Chicago Press, 1979).
} 
performed in New York City with a program titled American Dances. ${ }^{130}$ The evening included Dudley's Harmonica Breakdown (1938), which demonstrated the plight of workers and African-Americans in a work she called, "a misery dance." "131 Maslow performed Dust Bowl Ballads (1941) to the music of Woody Guthrie, expressing the continuing struggle of farm workers. The same year as American Dances, the NDG Board of Directors initiated a letter-writing campaign to free the jailed Earl Browder. ${ }^{132}$ In 1942, Maslow created Folksay, danced to Carl Sandberg's poem, "The People, Yes." One dancer remembered, "We were not Communists. We just believed everything they believed."133

The modern dance connection to the US government endured. During World War II, it utilized modern dancers. For example, Pvt. José Limón choreographed the army production of $H i$, Yank, with music by NDG composer Lt. Alex North, Anna Sokolow's partner. ${ }^{134}$ Limón had taught the men's class at the NDG, but solidified his career and choreography with Doris Humphrey and his own company. He was the first representative sent abroad by the State Department. In 1944, Graham premiered Appalachian Spring at the Library of Congress. ${ }^{135}$ After the war, the army made a film about modern dance featuring the NDG leaders Dudley and Maslow. ${ }^{136}$ These new works presented the art as uniquely American and a product that affirmed national ideology.

The Cold War created an ironic turn: the US government deployed the Soviet tactic of using dance as propaganda to fight the Soviets. In 1941, a government-funded operation had sent a ballet troupe that included George Balanchine and Lincoln Kirstein to Latin America to present American high art in politically contested areas. ${ }^{137}$ Balanchine deployed modernist techniques to interpret the ballet form. The two men would come together again to create the New York City Ballet (NYCB). Indeed, this was an embedded circle of borrowings. In this first American foray into international waters with dance the choreographer who directed the American ballet used by the US government in

\footnotetext{
${ }^{130}$ Program, American Dances, 1941, NDG archives.

${ }^{131}$ Jane Dudley, Harmonica Breakdown.

132 “Minutes," Board Meeting, April 1941, NDG archives.

${ }^{133}$ Mary Anthony, "Oral history with Mary Anthony," interview by Victoria Phillips Geduld, 2 August 2006, New York (CUOHRO, transcript available upon request).

${ }^{134}$ After World War II North composed the music for films such as Streetcar Named Desire, Spartacus, Cleopatra, 2001: A Space Odyssey, Who's Afraid of Virginia Woolf?, and Prizzi's Honor (see Albert Wertheim, "The dramatic art of Uncle Sam: the government, drama, and World War II," American Drama, Winter 2004, available online at: http://findarticles.com/p/articles/mi_qa4129/is_200401/ ai_n9372135/pg_7, accessed 23 April 2007).

${ }^{135}$ Appalachian Spring, choreography Martha Graham, music Aaron Copland, set Isamu Noguchi, 30 October 1944, Library of Congress, Washington, DC; Naima Prevots, Dance for Export: Cultural Diplomacy and the Cold War (Middletown, CT: Wesleyan University Press, 1998), 47.

136 "Creative leisure," US Department of the Army, producer Herbert Kerkow, 5 minutes, available at NYPL-DD. Includes scenes at Connecticut College School of Dance, and NDG members Valerie Bettis, Jane Dudley, Sophie Maslow, and William Bales.

${ }^{137}$ Prevots, Dance for Export, 25. The covert action protected the government from attachment to any possible failure. Note that in Orwell Subverted Leab shows the CIA funded covert projects as propaganda was being established after World War II.
} 
its propaganda war against the Soviets was himself Russian. George Balanchine was born Georgi Melitonovitch Balanchivadze, and had left the Soviet Union shortly after the government closed the Imperial School to privilege Duncan and the Bolshoi. After fleeing first to Europe, he was brought to the USA to experiment with new dance forms by Kirstein. Balanchine then became critically heralded as an American artist. He trained his ballerinas in a school named The School of American Ballet, as he proudly wore Western shirts and rope ties. The 1941 tour was a success. ${ }^{138}$ Ballet's new form represented American freedom. But modern dance did not always succeed in the early cultural battles with the USSR.

In 1947, the State Department organized a contingent of dancers to represent the USA at a Youth Festival in Prague; they selected NDG choreographers along with Graham and others to represent the nation in modern dance. ${ }^{139}$ The barefoot and free form had no counterpart in the Soviet Union, where modern artists had been suppressed, and thus the American form was an ideal propaganda tool. After the State Department withdrew its support because the Festival was perceived as a "Red Fete," only one NDG member remained to teach student amateurs on the boat over to the Festival and, as the New York Times put it, "Soviet Russia had 'stolen the show.",140

The poor American showing at the Prague festival caused concern. ${ }^{141}$ Private and public officials went to work. Imagined as the modern sibling of the NYCB, the New York City Dance Theatre (NYCDT) was formed to represent the nation in future competitions. NDG choreographers dominated the NYCDT. ${ }^{142}$ Its first program read: "The Dance seen on the stage is American-American in origin, in inspiration and in its highest development."143 After the first season, the ensemble company disintegrated, but the government was not deterred.

However, Cold War fervor determined the fate of many NDG choreographers as the government deployed modern dance. After 1950, the government

\footnotetext{
${ }^{138}$ Prevots, Dance for Export, 19.

${ }^{139}$ John Martin, "The dance: program," The New York Times, 1 June 1947, 10; Walter Terry, dance critic, The New York Herald-Tribune and Chairman, Continuations Committee of the American Dance Committee of the Youth Festival, to Morton Baum, Chairman, City Center, 15 December 1947, Morton Baum Papers, folder 266, available at NYPL-DD.

140 "World Youth Festival" in The Bright Face of Peace (New York: World Festival of Youth and Students for Peace and Friendship, 1947), 17, in file folder "Publications relating to World Festival of Youth and Students for Peace and Friendship," Tamiment Library, and Robert F. Wagner Archives, Bobst Library, New York University; Muriel Manings, “Oral history with Muriel Manings," interview by Victoria Phillips Geduld, 1 March 2007, New York (CUOHRO, transcript available upon request). Note that the early indecisive actions by the State Department and the CIA regarding international deployment of the arts reflect the institutional jockeying that took place within the government itself as it attempted to establish its post-war spy and espionage organizations. See Leab, Orwell Subverted; "Red Issue Splits Youth Delegates," The New York Times, 7 October 1947, 5.

141 "Rift of U.S. group in Budapest noted," The New York Times, 3 September 1949, 3.

${ }^{142}$ Walter Terry to Morton Baum, 15 December 1947, Morton Baum Papers, folder 266, available at NYPL-DD.

${ }^{143}$ Isadora Bennett, "NY dance theater," Isadora Bennett Papers, folder 22-176, available at NYPL-DD.
} 
wanted no artist who had been closely associated with the Soviets and developed dances of protest. The government overlooked dance troupes led by NDG choreographers for State Department tours; as blacklists arose the Cold War apparatus even turned on the dancers. The NDG was identified by the FBI as an organization run by Communists. The government identified Dudley's name and Communist Party membership number, her name appeared in Red Channels, and she suffered accordingly. Her husband was blacklisted. Maslow's participation in the World Youth Festival and work at the NDG, as well as reviews in The Daily Worker, served as FBI evidence of her subversion. Her brother lost his job at a military plant. The State Department revoked Sokolow's passport, and after she managed to get back to Mexico, her movements were monitored. ${ }^{144}$ FBI informants code-named T-1 and T-6 divulged the activities and voting patterns of numerous dancers and choreographers. The voting records of the 1930s that Roosevelt had defended served as proof of the dancers' subversion. ${ }^{145}$ The FBI visited the home of a NDG founder who had left the NDG to go to the WPA in $1935 .{ }^{146}$ Although NDG choreographers and dancers worked on Broadway, and even in colleges, scheduled appearances such as Maslow's performance on Ed Sullivan's TV show were called off with no explanation. ${ }^{147}$

Many theatrical personalities appeared before the House Un-American Activities Committee (HUAC), and some named names. Yet Congress called only one choreographer to testify: the former Communist Party member Jerome Robbins, who had been a NDG student and who had choreographed and performed with the NDG's professional company. ${ }^{148}$ Robbins had achieved fame with his Fancy Free (1944), had choreographed The King and I (1951), and wanted to work in Hollywood. ${ }^{149}$ He testified before the House Committee and named Edna Ocko, the NDG and WDL founder. ${ }^{150}$

\footnotetext{
${ }^{144}$ U.S. Department of State, Case control number 200001994, Sokolow, Anna. Obtained under Freedom of Information Act Exemptions (5 USC 552). Copy available from author upon request.

${ }^{145}$ See also FBI files of Jane Dudley, Sophie Maslow, Pearl Primus, and Edna Ocko.

${ }^{146}$ Rosenberg, "Oral history with Rebecca Rosenberg."

147 “Interview with Abby Maslow Blatt,” by Victoria Phillips Geduld, 1 April 2007, New York City, transcript available upon request.

148 "New dance group," Dance Observer, June-July 1940, 85. Jerome Robbins and Anita Alverez performed and choreographed Strange Fruit (1940) at the Heckscher Theatre, 19 May 1940 under the NDG (NDG archives). Note that Amanda Vaill discussed Robbins' training at the NDG in Somewhere: The Life of Ferome Robbins (New York: Broadway, 2006). Unfortunately, she wrote that Robbins took "classes at the WPA and the NDG (originally the WDL), an avant-garde Olympus where gods of the modern movement, Martha Graham, and Charles Weidman and Doris Humphrey and Helen Tamiris, and their disciples danced and taught" (34). Neither Graham, Humphrey, nor Tamiris taught at the NDG, and the NDG was never the WDL. Deborah Jowitt in Ferome Robbins: His Life, His Theater, His Dance (New York: Simon \& Schuster, 2005) discusses Robbins' training in choreography at the NDG, but does not mention that he performed or choreographed with the group.

${ }^{149}$ Fancy Free, Metropolitan Opera House, New York, 18 April 1944, choreography Jerome Robbins, music Leonard Bernstein, scenery Oliver Smith; The King and I, choreography Jerome Robbins, music Richard Rodgers, lyrics and book Oscar Hammerstein II, St James Theatre, New York, 29 March 1951.

150 "Testimony of Jerome Robbins, "Investigation of Communist activities in the NYC area-Part 2," US House of Representatives, 83rd Congress, first session, Committee on Un-American Activities, Public hearing, 5 May 1953, Foley Square, New York, Hon. Harold H. Velde, Chair, 1331-1325.
} 
Just as the Soviet state mandated subjects to its artists, during the Cold War some in the USA echoed the didactic tenets of the Soviets. Before Robbins was allowed to leave, a HUAC member declared to Robbins: "You are blessed with a God given talent. ... Be very vigorous and positive in promoting Americanism in contrast to Communism." Robbins replied, "Sir, all my works have been acclaimed for its (sic) American quality particularly." The Congressman retorted, "I realize that." $\mathrm{He}$ continued: "Let me urge you to even put more of that [Americanism] in it."151 The government deployed dance in its cultural offensive, and in some instances dictated subject matter to American choreographers. Those who complied were rewarded.

Imitating the Soviets, during the 1950s the American government institutionalized its decision to use dance as nationalist propaganda with state-funded programs. After 1954, the State Department deployed specially chosen modern dance companies to hotly contested international areas. ${ }^{152}$ The NDG hosted choreographers Mary Anthony and Donald McKayle, who presented anti-Un-American dances. Limón and Graham were hired by the State Department. It also dispatched Graham to Japan, Indochina, and the Middle East with Appalachian Spring, which was pure Americana theatre, set on the American "frontier," in the Frederick Jackson Turner sense of the word, and replete with husbandman and his wife, a pioneer woman, a preacher, and followers (Aaron Copland had received the Pulitzer Prize in Music for the score) ${ }^{153}$ Isamu Noguchi's abstracted set included a log cabin home, a pulpit, and a fence. The work embodied the American dream in the readable language of modern theatrical dance.

Just before Graham left on the State Department tour in the spring of 1955, the New Dance Group appeared on Broadway alongside her company as a part of a festival entitled American Dance. Sokolow in her new work Rooms (1955) stole the show from Graham as the wife in Appalachian Spring. ${ }^{154}$ Sokolow portrayed the alienation of the isolated individual in this new ideologically stripped society. After the performance the triumphant Sokolow quietly returned to Mexico and worked in Israel, even re-entering Russia via these countries to show her dances. Humiliated for only a moment, Graham began her celebrated State Department tour on which she and her dancers were

\footnotetext{
151 “'Testimony of Jerome Robbins," 1325.

${ }^{152}$ Prevots, Dance for Export, 9.

${ }^{153}$ Appalachian Spring was based on Simple Gifts, written by Shaker Elder Joseph Brakett Jr in 1848. It was first published in The Gift to Be Simple: Shaker Rituals and Songs. Simple Gifts was a work song. Aaron Copland won the Pulitzer Prize for Music for the score originally entitled "Ballet for Martha."

${ }^{154}$ Rooms, Theresa L. Kaufman Auditorium, YM/YWHA, New York City, 24 February 1955, choreography Anna Sokolow, music Kenyon Hopkins, costumes Donald McKayle; John Martin, "Dance: study in despair," New York Times, 16 May, 1955, 26; see also Terry, I Was There, 298; "Reviews of the month," Dance Observer, 6 (June/July 1955), 83-7; Larry Warren, Anna Sokolow: The Rebellious Spirit (Princeton, NJ: Princeton Book Co., 1991), 155.
} 
received by dignitaries and regaled by the press as a symbol of America. ${ }^{155}$ Subsequently, Graham and Copland received grants from private foundations funded by the CIA. ${ }^{156}$

The NDG survived, chameleon-like. Incorporating and purchasing a building in 1955, the organization stepped into the capitalist system as a legal organization and a property owner. Yet the NDG's links to the past echo in its documents. The deed for the building is dated February 10, 1955, the 23rd anniversary of the NDG's inception and the shooting of Harry Simms. Jane Dudley's name linked both moments. In 1933 she choreographed Charity for the NDG, which appeared on the program brochure mourning Harry Simms. Her signature appears at the top of the 1955 building deed.

Relegated to small performance houses in the United States NDG choreography became more personal and less political. Political protest had been immobilized. After achieving notoriety on the college circuit, when Maslow was asked about her early association with the NDG she replied, "We're on tape." 157 The modern dancer whose form was based on individual freedom had learned she was not free to speak. Yet as the NDG borrowed capitalist economic strategies and made less overtly political dances, a new generation of Communists looked back to the US former workers group for a dance language. After establishing his power, Fidel Castro invited NDG members to Cuba to teach the modern form for revolutionary cultural production. $^{158}$

While striving to "counteract Russian propaganda," in the Cold War the State Department copied early Soviet methodology and deployed "Art as a Weapon."159 In the heat of this battle, some Congressmen even emulated the Soviet's didactic posture by dictating content to artists. Under Stalin the consequences of state mandates were extreme. In the United States radicalized American artists continued to work, yet did so with an American dance drained of overt political protest as the government tried to dictate nationalist content and funded artists who complied. Blacklists shut down mass performing venues for those who did not. The irony was that this suppression of expressive freedom was executed in the name of freedom. Artistic containment and alienation was the unfortunate fallout of a Cold War policy that used dance as a weapon.

\footnotetext{
155 “'Ethel Winter Oral History with Victoria Geduld,” 24 September 2004, New York City, COHRO, transcript available upon request.

${ }^{156}$ Francis Stonor Saunders, The Cultural Cold War: The CIA and the World of Arts and Letters (New York: New Press, 2000).

${ }^{157}$ Maslow, "Interview with Sophie Maslow."

${ }^{158}$ Manings, "Oral history with Muriel Manings."

159 “Dance Panel Meeting: International Exchange Program,” 21 October 1954, New York City. Mr Robert C. Schnitzer, International Exchange Program, told the Dance Panel, "The State Department is particularly interested in [works] to counteract Russian propaganda." Special Collections Division, University of Arkansas Libraries, Fayetteville, AR. Special thanks to Professor Naima Prevots.
} 
Copyright of American Communist History is the property of Routledge and its content may not be copied or emailed to multiple sites or posted to a listserv without the copyright holder's express written permission. However, users may print, download, or email articles for individual use. 